\title{
Development and Quality Evaluation of Barnyard Millet Bran Incorporated Rusk and Muffin
}

Nazni P* and Karuna TD

Department of Food Science and Nutrition, Periyar University, Salem, India

\begin{abstract}
Introduction: Millets are good sources of energy, protein, fatty acids, vitamins, minerals, dietary fibre and polyphenols. Millet bran is therefore a by-product of millet-based food manufacturing.

Background: The chemical treatments will decrease the content of anti-nutrients and increase the content of compounds that improve bioavailability.

Objectives: The present study with the objectives to study the different method of chemical treatment in barnyard millet bran, and the treated bran and raw bran was analysed for the antinutrional and proximate composition.

Materials and Methods: Various pre-treatment done by chemical treatments in Barnyard millet bran, antinutritional and chemical composition and texture analysis were analysed using standard techniques.

Results and Conclusion: The various chemical treated bran the calcium hydroxide and hot water treated [treatment-2] barnyard millet bran get decrease the antinutrient factors such as trypsin inhibitor, lipase activity, phytates etc., when compare to raw barnyard millet bran. From the chemical analysis the dietary fibre, protein, ash content was stabilized in [treatment-2] treated bran when compare to other treated bran. The sensorial attributes of rusk at ratio $(85: 15)$ and muffin at ratio $(75: 25)$ with BMB substitution got highly accept by panel members. Even though BMB slightly increased the hardness of rusk and in muffin increase the strength of muffin.
\end{abstract}

Keywords: Bran; Barnyard millet; Chemical treatment; Antinutritional

\section{Introduction}

Millets are more nutritious and they are non-glutinous and nonacid forming and easy to digest. Millets are good sources of energy, protein, fatty acids, vitamins, minerals, dietary fibre and polyphenols. Millets are rich in essential amino acids, methionine, and cysteine and are higher in fat content than maize, rice and sorghum [1]. The most important minor millets cultivated in India are barn-yard millet, kodo millet, little millet, guinea millet and browntop millet. Millets are more nutritious and they are non-glutinous and non-acid forming and easy to digest. Barnyard, Japanese barnyard or sawa millet is the fastest growing of all millet and produces a crop in six weeks. It is grown in India, Japan and China as a substitute for rice. The grain is $2-3 \mathrm{~mm}$ long and 1-2 mm wide [2]. Bran is an outer layer of most cereal grains, which is nutrient dense as it contains proteins, omega 3 and omega 6 fatty acids and antioxidants [3]. Cereal bran is an excellent source of dietary fibre which is used for the addition to food offers all the nutritional and nutraceutical benefits of whole grain [4]. Millet bran is therefore a by-product of millet-based food manufacturing [5]. Recent studies have reviewed the classification and clinical indications of various formulations of calcium hydroxide and their mechanisms of antimicrobial activity [6] (Siqueira and Lopes), clearly indicating that even though this medication has been used for more than 80 years, there are still many questions to be answered regarding its antimicrobial action [7]. Acetic acid has a distinctive sour taste and pungent smell [8]. Millets have great potential for being utilized in different food systems by virtue of their nutritional quality and economic importance [9]. There is a wide scope of their exploitation in different food products including baked goods like breads, biscuits, cakes, cookies, breakfast cereals, muffins, pies, pancakes, snacks and extruded food stuffs. The present study with the objectives to study the different method of chemical treatment in barnyard millet bran, and to develop bran incorporated bakery product, the treated bran were analysed for antinutrient and proximate composition. The products were analysed for texture and sensory.

\section{Materials and Methods}

\section{Collection of samples}

Grain samples of whole Barnyard millet were collected from Local market of Salem district, of Tamilnadu. Barnyard millet was cleaned and the bran was removed by milling. 1 kilogram of the whole barnyard millet contains 350 gram of bran. The sample was then cleaned properly, shade dried and grinded manually and sieved through a 60 mesh sieve (BSS) to collect the bran. Then the bran sample was stored in sealed containers till their use in different experimental procedures. The other ingredients were purchased from the local market.

\section{Pre-treatment of barnyard millet bran}

After the removal of bran from the barnyard millet and it was immediately subjected in to various chemical treatments to reduce the anti-nutritional components (17). The various treatments done in barnyard millet bran given in Table 1:

After completion of all chemical treatments in bran, each treated

*Corresponding author: Nazni P, Department of Food Science and Nutrition, Periyar University, Salem, India, Tel: 98848 17954; E-mail: naznip@gmail.com

Received September 12, 2016; Accepted October 03, 2016; Published October 07,2016

Citation: Nazni P, Karuna TD (2016) Development and Quality Evaluation of Barnyard Millet Bran Incorporated Rusk and Muffin. J Food Ind Microbiol 2: 116. doi:10.4172/2572-4134.1000116

Copyright: @ 2016 Nazni P, et al. This is an open-access article distributed under the terms of the Creative Commons Attribution License, which permits unrestricted use, distribution, and reproduction in any medium, provided the original author and source are credited. 


\begin{tabular}{|l|l|}
\hline Control[RBMB] & Barnyard millet Bran termed as Raw Barnyard millet bran was left untreated and used as control. \\
\hline Treatment-1 & Mix bran and soak with $20 \% 1 \%$ acetic acid filtered and soak in $0.07 \%$ sodium bicarbonate solution, finally filtered and dried at $50^{\circ} \mathrm{C}$ \\
\hline Treatment-2 & $\begin{array}{l}\text { Soaking bran in hot water }\left(125^{\circ} \mathrm{C}\right) \text { for } 15 \text { minutes, filtered and mixed with } 20 \% \text { solution of } 1 \% \text { calcium hydroxide , finally filtered and dried } \\
\text { at } 50^{\circ} \mathrm{C}\end{array}$ \\
\hline Treatment-3 & $\begin{array}{l}\text { The sieved bran will be washed by water or base wash by stirring } 200 \mathrm{~g} \text { sieved bran in } 2 \mathrm{~L} \text { of deionised water or } 4 \mathrm{~L} \text { of } 0.1 \mathrm{M} \mathrm{NaOH} \\
\text { respectively. The water washed or base washed bran will be dried overnight at } 50^{\circ} \mathrm{C} \text {. Ground wheat bran will be mixed in } 0,5 \mathrm{~mol} / \mathrm{l} \text { of citric } \\
\text { acid }(\mathrm{CA}) \text { at the ratio of } 1: 12 \text { (bran:acid, w/v) and stirring for } 30 \text { min. The acid/bran slurry will be dried at } 50^{\circ} \mathrm{C} \text { in a forced air oven for } 24 \mathrm{hr} \\
\text { to remove residual alkali. }\end{array}$ \\
\hline
\end{tabular}

Table 1: Pre-treatment of Barnyard Millet Bran.

bran were dried and made in to flours. The developed barnyard millet bran flour was packed in air impermeable plastic bags.

\section{Analysis of antinutritional and nutrient analysis for raw and chemical treated barnyard millet bran}

The anti-nutritional factors such as lipase activity, peroixidase activity [Vetter method (2000)], phytic acid determined by the method of Haug and Lantzesch, Total phosphorous [10], and trypsin inhibitor were assessed using standard procedures. Various chemical treatments have been employed in attempt to decrease the antinutrional value of bran [11].

All samples were analysed for contents of such as moisture, carbohydrate, protein, fat, fibre, ash, nitrogen free extract, starch and total phosphorus, were determined using [10] method. All the estimations were done in triplicates.

From the antinutrient and nutrient analysis of various chemical treated bran the treatment- 2 got decrease antinutrient content when compare to other treatment so the [treatment-2] treated bran is incorporated in bakery products.

\section{Preparation of Millet Bran Flour Incorporated bakery Products}

The bakery products such as rusk and muffin were prepared using best chemical treated barnyard millet bran. The rusk and muffin were prepared by incorporation of millet bran flour by various levels. The prepared rusk and muffin was analysed for their, texture profiles and sensory qualities.

\section{Rusk formulation and preparation}

Seven formulations of millet bran rusk were prepared. Each formulation varied by ratio of wheat flour to BMB Table 2. Basic formulation the ingredients were weighed accurately. Water and yeast were mixed in a separate pan and then transferred to the kneader containing flour, sugar, shortening and salt. After homogeneous mixing, the dough was placed in a proofer for 15 minutes to activate the yeast. After the said time, it was again transferred to the mixer and oil was added and mixing was continued until dough became somewhat elastic. The dough was divided into dough balls (50 g), transferred to pans and received proofing time of 15 minutes. Afterwards, loaves were baked in a baking oven for $10-12$ minutes at $218^{\circ} \mathrm{C}$. Loaves were cooled down and cut into two pieces and again baked until the required color was obtained.

\section{Muffin formulation and preparation}

In the present study, seven different formulations of muffin were prepared. One formulation was prepared without BMB (control) and another six were formulated with BMB at different levels as shown in Table 1. The proportion of ingredients were based on [12] with some modifications. They were divided into dry and wet ingredients. The dry

\begin{tabular}{|c|c|c|}
\hline Variations & Wheat flour $(\mathbf{g})$ & BMB \\
\hline V1(control) & 100 & 0 \\
\hline V2 & 95 & 5 \\
\hline V3 & 90 & 10 \\
\hline V4 & 85 & 15 \\
\hline V5 & 80 & 20 \\
\hline V6 & 75 & 25 \\
\hline V7 & 70 & 30 \\
\hline
\end{tabular}

Table 2: Variations for the preparation of bakery products. BMB: Barnyard mille bran.

ingredients included wheat flour, baking powder, sugar and BMB. The wet ingredients were egg, milk and oil. The egg was beaten for $2 \mathrm{~min}$ prior to addition of milk and oil. In a separate bowl, all dry ingredients were thoroughly mixed. Later, both dry and wet ingredients were combined to obtain mixed muffin batter. Thirty $g$ of batter were filled in each $45 \mathrm{~mm}$ diameter paper muffin cup. The muffins were baked at $215^{\circ} \mathrm{C}$ in oven (Zanussi ZCG841W) for $15 \pm 3 \mathrm{~min}$

\section{Sensory Evaluation}

Sensory evaluation session was conducted based on 7-point hedonic scale [13] where higher score indicates better quality attributes (1, dislike very much and 7 , like very much). Sensory attributes such as colour, aroma, appearance, crispiness and flavour of rusk were evaluated. Meanwhile, for muffin, evaluation was made for the following attributes: Appearance, texture, taste and flavour, overall acceptability [12]. Each attribute was independently judged by 60 untrained panels based on their likeness. Seven samples of each product were served to every panel. Each sample was presented with three-digit code. Random permutation principle was followed to determine serving order. The sensory scores of the rusk and muffin for each parameter were subjected to statistical analysis to calculate mean scores.

\section{Texture profile analysis (TPA) of bakery products}

Texture analysis of the standardized rusk and muffin was done by using the Texture Analyzer TAXT2 with exponent software. The hardness and fracturability of the rusk were analyzed. rusk in triplicate were put in the analyzer where once the trigger force was attained; the force was seen to increase until such time till the biscuit fractures and breaks into pieces. This is observed as the maximum force and can be referred to as 'hardness' of the sample. The distance at the point of break is the resistance of the sample to bend and so relates to the 'fracturability' of the sample. Instrumental analysis of muffin textural properties was performed to record hardness, springiness, cohesiveness, resilience and chewiness [14]. The soft inner portion of muffin was evaluated. Each muffin was cut into $2.5 \mathrm{~cm}$ sided cube, where the upper and lower crusts were eliminated. A $75 \mathrm{~mm}$ diameter aluminium plate $(\mathrm{P} / 75)$ was used for compression. The test was performed under the following states: Test speed: $1 \mathrm{~mm} / \mathrm{s}$; strain: $50 \%$ and trigger force: $5 \mathrm{~g}$. Muffin cube was compressed twice to obtain the four primary texture parameters (hardness, springiness, cohesiveness 
and resilience). Chewiness, the only secondary texture parameter, was calculated as the product of hardness $\times$ cohesiveness $\times$ springiness. The results were obtained in the form of a graph, force vs time or distance.

\section{Statistical analysis}

The final data was compiled and analyzed by using statistical methods. The results were represented as Descriptive statistics such as mean, standard deviation followed by Duncan's multiple comparison tests were considered significant.

\section{Result and Discussion}

\section{Antinutritional factors and chemical Composition in raw and chemical treated barnyard millet bran}

The antinutritional factors such as lipase activity, peroxidase activity, phytic acid, and total phosphorous, trypsin inhibitor were analysed in both raw and chemical treated bran. The chemical composition such as $\mathrm{CHO}$, protein, fat, fiber, and total ash, total starch was analysed both raw and chemical treated bran. The result shown Figure 1 described below;

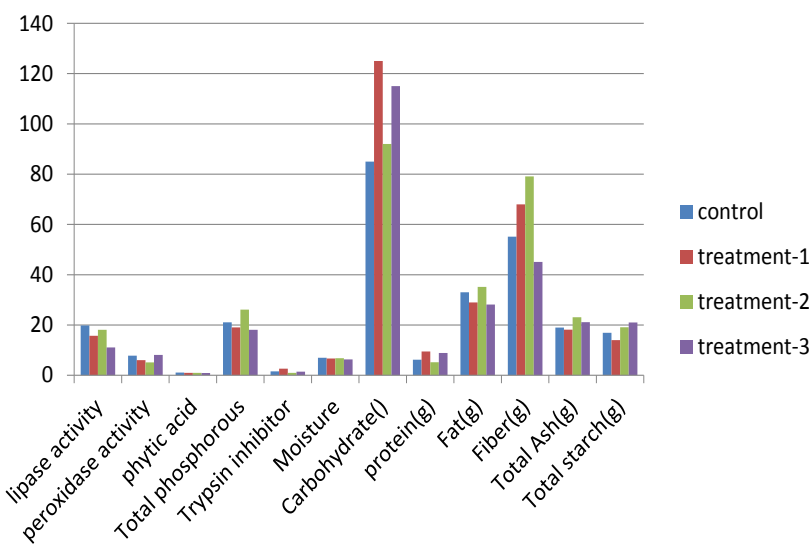

Figure 1: Antinutritional factors and chemical Composition in raw and chemical treated barnyard millet bran.
From the above Figure 1 shows that the antinutritonal factors are increase in raw bran when compare to chemical treated bran. In chemical treated bran (treatment-2) bran get decrease level of antinutritional factors next to other treated bran. Decreasing of phytic acid is very advantageous due to its influence on nutrition therefore interest has been grown to reduce its antinutritional effect [3]. Phytic acid as powerful chelating agent reduces the bioavailability of divalent cations by the formation of insoluble complexes [15]. From the analysis of antinutrient factors in chemical treated bran the (treatment-1) treated barnyard millet bran got maximum antinutrient and minimum chemical component when compare to other chemical treated bran. From the proximate composition like protein (5.19), fiber (45.10), ash (23.10), starch (19.12) has slightly increase in (treatment-2) treated barnyard millet bran when compare to raw bran and other treated bran. In (treatment-1) treated bran nutrient content was decreased.

\section{Texture profile Analysis of developed bakery product}

Texture profile analysis of rusk and muffin such as hardness, peak time, stickness, strength were analysed and discussed below Table 3 and Figure 2.

Figure 3 The incorporation of BMB slightly increased hardness attribute of rusk at variation 2 Table 1 In other study, replacement of wheat flour by peach dietary fibre in muffin has increased hardness due to increase in density and reduce number of air pocket $[16,17]$. In rusk at peak time nevertheless, significant difference was only observed at $20 \%$ BMB incorporation. Peak time increase may possibly cause the increase in hardness. Strength was found to gradually increase with higher level of BMB incorporation. Muffin with 75:25 ratio formulations had lower strength, which significantly differed from control. Meanwhile, Decrease in springiness has been related to reduce number of muffin air bubbles and the presence of a denser matrix [18]. The sickness of muffin get increase in ratio $(90: 10)$.

\section{Sensory Evaluation of developed bakery product}

The sensory evaluation of prepared rusk and muffin were discussed below Table 4 and 5:

The statistical results showed that sensorial attributes scores of rusk at $30 \% \mathrm{BMB}$ at and muffin at $15 \% \mathrm{BMB}$ incorporation were

\begin{tabular}{|c|c|c|c|c|c|}
\hline \multirow[t]{2}{*}{ Variation } & \multicolumn{2}{|c|}{ Muffin } & \multicolumn{3}{|c|}{ Rusk } \\
\hline & Hardness & Peak time & Hardness & Stickness & Strength \\
\hline V1(control) & $3.32 \pm 1.527^{\mathrm{b}}$ & $17.41 \pm 0.051^{a}$ & $4.54 \pm 0.417^{c}$ & $-0.33 \pm 0.152^{d}$ & $90.54 \pm 0.155^{c}$ \\
\hline V2 & $5.180 \pm 0.025^{\mathrm{e}}$ & $17.48 \pm 0.015^{\mathrm{b}}$ & $9.6787 \pm 0.403^{d}$ & $-12.0 \pm 0.000^{a}$ & $1.93 \pm 0.010^{\mathrm{b}}$ \\
\hline V3 & $3.78 \pm 1.00^{c}$ & $17.43 \pm 0.015^{\mathrm{a}}$ & $5.60 \pm 0.283^{\mathrm{e}}$ & $-2.00 \pm 0.00^{c}$ & $1.1250 \pm 0.675^{\mathrm{e}}$ \\
\hline V4 & $1.52 \pm 28.04^{d}$ & $17.44 \pm 0.040^{\mathrm{a}}$ & $5.0868 \pm 0.883^{d}$ & $-0.03 \pm 0.057^{d}$ & $1.0330 \pm 0.900^{\mathrm{d}}$ \\
\hline V5 & $6.28 \pm 0.052^{g}$ & $17.50 \pm 0.010^{c}$ & $1.58 \pm 0.251^{\mathrm{b}}$ & $-2.00 \pm 0.000^{c}$ & $31.40 \pm 0.608^{a}$ \\
\hline V6 & $4.18 \pm 0.527^{d}$ & $17.48 \pm 0.015^{b}$ & $5.72 \pm 0.806^{f}$ & $-0.40 \pm 0.100^{d}$ & $1.1361 \pm 0.025^{d}$ \\
\hline V7 & $5.070 \pm 0.645^{b}$ & $17.48 \pm 0.010^{\mathrm{b}}$ & $3.6196 \pm 0.891^{b}$ & $-5.33 \pm 0.152^{b}$ & $71.93 \pm 0.550^{\mathrm{b}}$ \\
\hline
\end{tabular}

Table 3: Texture profile Analysis of rusk and muffin developed bakery product. Values are mean \pm standard deviations. Mean in the same column with different letter diffe significantly $(p<0.05)$.

\begin{tabular}{|c|c|c|c|c|c|c|}
\hline Variation & Appearance & Colour & Flavour & Texture & Crispness & Overall acceptability \\
\hline V1 (control) & $8.2857 \pm 0.48795^{a}$ & $7.7143 \pm 0.959^{a}$ & $8.1429 \pm 0.6900^{a}$ & $7.8571 \pm 0.6900^{a}$ & $8.0000 \pm 0.535^{a}$ & $8.2857 \pm 0.48795^{a}$ \\
\hline V2 & $8.2857 \pm 0.4879^{a}$ & $7.1429 \pm 0.894^{\mathrm{a}}$ & $8.1429 \pm 0.6900^{a}$ & $8.0000 \pm 0.8165^{a}$ & $8.1429 \pm 0.6900^{a}$ & $8.4286 \pm 0.53452^{\mathrm{a}}$ \\
\hline V3 & $8.2857 \pm 0.48795^{\mathrm{a}}$ & $7.4286 \pm 0.9750^{a}$ & $7.4286 \pm 0.9759^{a}$ & $8.1429 \pm 0.6900^{a}$ & $7.7143 \pm 0.7559^{a}$ & $7.4286 \pm 0.53452^{\mathrm{a}}$ \\
\hline V4 & $8.0000 \pm 0.81650^{a}$ & $8.2857 \pm 0.4875^{a}$ & $7.8680 \pm 0.2973^{a}$ & $8.0000 \pm 0.8165^{a}$ & $8.2857 \pm 0.4879^{a}$ & $8.1429 \pm 0.69007^{\mathrm{ab}}$ \\
\hline V5 & $7.4286 \pm 0.97590^{\mathrm{a}}$ & $7.42861 \pm 0.397^{a}$ & $7.5593 \pm 0.2857^{a}$ & $8.2857 \pm 0.7559^{a}$ & $8.0000 \pm 0.8165^{a}$ & $8.1429 \pm 0.89974^{\mathrm{ab}}$ \\
\hline V6 & $7.7143 \pm 0.75593^{a}$ & $7.2857 \pm 0.7559^{a}$ & $9.7590 \pm 0.3688^{a}$ & $7.7143 \pm 0.4879^{a}$ & $7.5714 \pm 0.5345^{a}$ & $7.7143 \pm 0.75593^{\mathrm{ab}}$ \\
\hline V7 & $7.8571 \pm 0.89974^{a}$ & $7.5714 \pm 0.5345^{a}$ & $5.7735 \pm 0.2182^{a}$ & $7.42861 \pm 0.272^{a}$ & $.69007 \pm 0.2608^{a}$ & $8.1429 \pm 0.69007^{\mathrm{ab}}$ \\
\hline
\end{tabular}

Table 4: Sensory evaluation of rusk. Values are mean \pm standard deviations. Mean in the same column with different letter differ significantly $(p<0.05)$. 


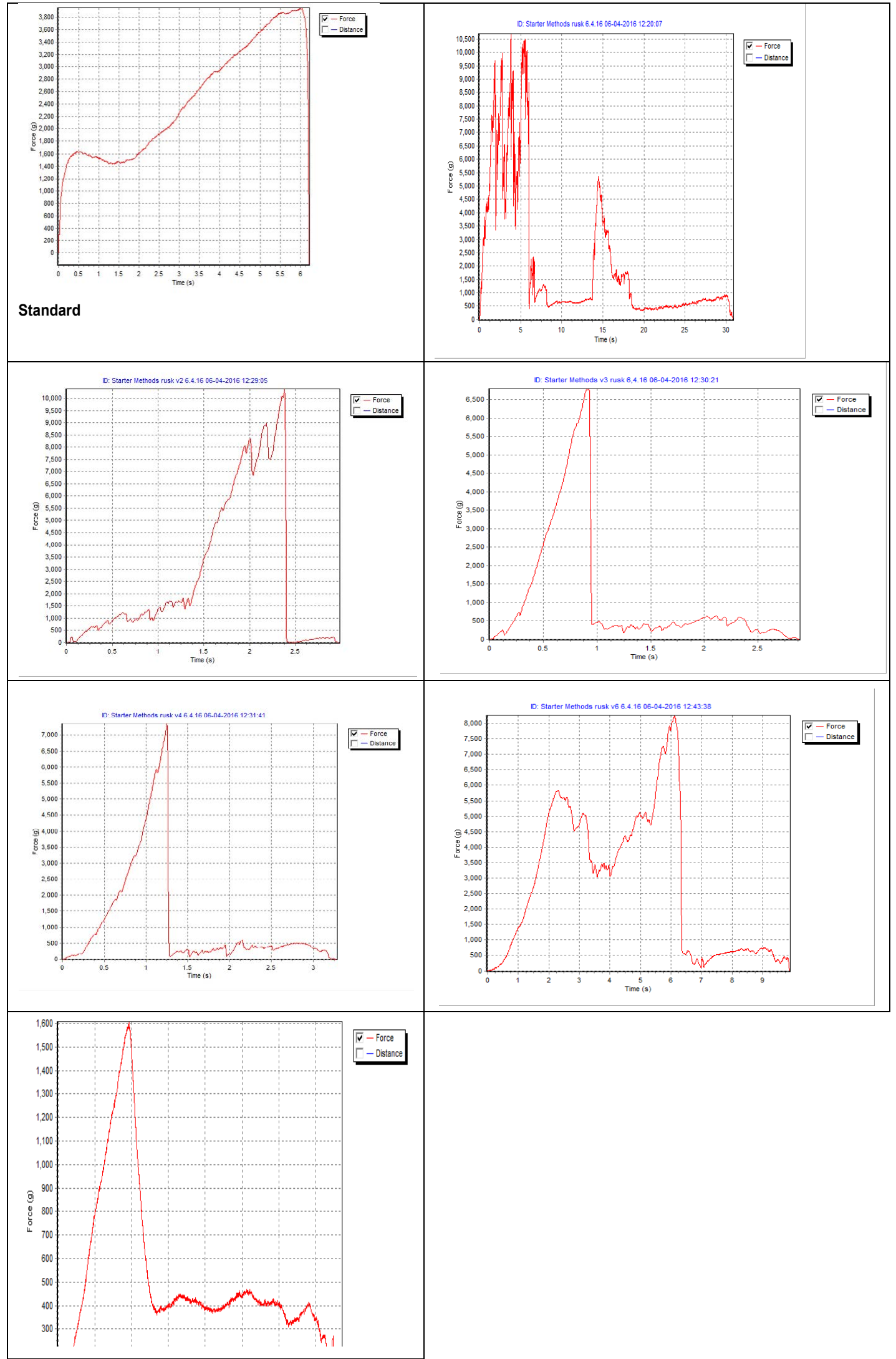

Figure 2: Texture profile analysis of rusk. 


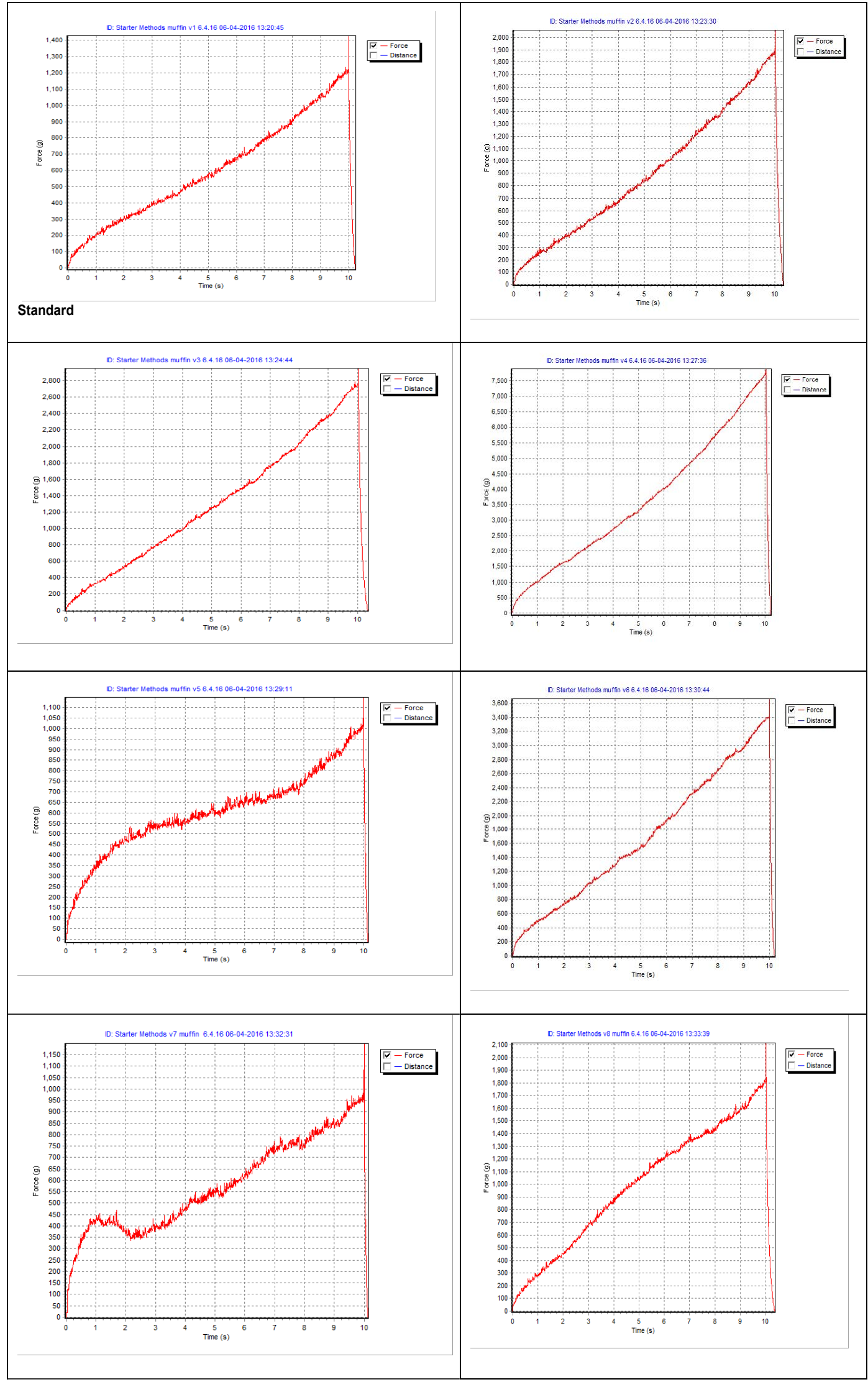

Figure 3: Texture profile analysis of muffin 
Citation: Nazni P, Karuna TD (2016) Development and Quality Evaluation of Barnyard Millet Bran Incorporated Rusk and Muffin. J Food Ind Microbiol 2: 116. doi:10.4172/2572-4134.1000116

Page 6 of 6

\begin{tabular}{|c|c|c|c|c|c|c|}
\hline Variation & Appearance & Colour & Flavour & Texture & Crispness & Overall acceptability \\
\hline V1 (control) & $8.2857 \pm 0.4879^{\mathrm{a}}$ & $7.7143 \pm 0.95119^{\mathrm{ab}}$ & $8.1429 \pm 0.69007^{\mathrm{a}}$ & $7.8571 \pm 0.6900^{\mathrm{a}}$ & $8.0000 \pm 1.00000$ & $8.2857 \pm 0.48795 \mathrm{~b}^{\mathrm{c}}$ \\
\hline V2 & $8.2857 \pm 0.4879^{\mathrm{a}}$ & $7.1429 \pm 0.89974^{\mathrm{a}}$ & $8.1429 \pm 0.69007^{\mathrm{a}}$ & $8.0000 \pm 0.8165^{\mathrm{a}}$ & $8.0000 \pm 0.81650^{\mathrm{ba}}$ & $8.4286 \pm 0.53452^{\mathrm{c}}$ \\
\hline V3 & $8.2857 \pm 8.285^{\mathrm{a}}$ & $7.4286 \pm 0.97590^{\mathrm{ab}}$ & $7.4286 \pm 0.97590^{\mathrm{a}}$ & $.81650 \pm 0.6900^{\mathrm{a}}$ & $8.4286 \pm 0.53452^{\mathrm{b}}$ & $7.4286 \pm 0.53452^{\mathrm{ab}}$ \\
\hline V4 & $8.0000 \pm 0.8165^{\mathrm{a}}$ & $8.2857 \pm 0.48795^{\mathrm{b}}$ & $7.5714 \pm 0.78680^{\mathrm{a}}$ & $8.0000 \pm 0.8165^{\mathrm{a}}$ & $7.4286 \pm 1.71825^{\mathrm{ab}}$ & $8.1429 \pm 0.69007^{\mathrm{bc}}$ \\
\hline V5 & $7.4286 \pm 0.9759^{\mathrm{a}}$ & $7.4286 \pm 1.39728^{\mathrm{ab}}$ & $7.2857 \pm 0.7559^{\mathrm{a}}$ & $8.2857 \pm 0.75593^{\mathrm{a}}$ & $7.1825 \pm 0.69007^{\mathrm{ab}}$ & $8.1429 \pm 0.89974^{\mathrm{bc}}$ \\
\hline V6 & $7.7143 \pm 0.7559^{\mathrm{a}}$ & $7.2857 \pm 0.75593^{\mathrm{ab}}$ & $7.5714 \pm 0.97590^{\mathrm{a}}$ & $7.7143 \pm 0.48795^{\mathrm{a}}$ & $6.8571 \pm 1.95180^{\mathrm{a}}$ & $7.1429 \pm 1.06904^{\mathrm{a}}$ \\
\hline V7 & $7.8571 \pm 0.8997^{\mathrm{a}}$ & $7.5714 \pm 0.53452^{\mathrm{ab}}$ & $8.0000 \pm 0.57735^{\mathrm{a}}$ & $7.4286 \pm 1.27242^{\mathrm{a}}$ & $7.5714 \pm 0.97590^{\mathrm{ab}}$ & $8.0000 \pm 0.81650 \mathrm{~b}^{\mathrm{c}}$ \\
\hline
\end{tabular}

Table 5: Sensory evaluation of muffin. Values are mean \pm standard deviations. Mean in the same column with different letter differ significantly $(p<0.05)$

significantly better than controls Figure 2 . Overall acceptance score of rusk formulations at 85:15 ratio $(8.14 \pm 0.69)$ and for muffin $70: 30$ ratio $(7.14 \pm 1.06)$ of wheat flour to $\mathrm{BMB}$ had the highest hedonic score among all formulations. Control rusk scored significantly less $(7.851 \pm 0.69)$ than rusk supplemented with BMB $(8.14 \pm 0.69)$ in term of texture. BMB incorporation at had also improves the cripness acceptance score of muffin, $(8.28 \pm 0.487)$ compared with $(8.00 \pm 0.57)$ of control muffin. Appearance score of rusk and muffin at (85:15) did not differ significantly from control. This finding was in agreement with other study, where the researchers found that sensory acceptance of bakery products, i.e. several Indian snack foods and savouries, sweet products and pickles were higher than control $[17,18]$

\section{Conclusion}

This study showed that protein and dietary fibre contents significantly increased as more BMB (Branyard millet bran) was incorporated. From the various chemical treatments like acetic acid [treatment-1], calcium hydroxide and hot water [treatment-2], citric acid [treatment-3] and raw bran were taken for analysis. From this treatment- 2 treated, barnyard millet bran get decrease the antinutrient factors such as trypsin inhibitor, lipase activity, phytates etc., when compare to raw barnyard millet bran. The proximate analysis (dietary fibre, ash, starch) was stabilized in [treatment-2] treated bran when compare to other treatments. The results also suggested that BMB is potentially added into carbohydrate-based foods such as rusk and muffin due to its higher acceptance score. The sensorial attributes of rusk at ratio (85:15) and muffin at ratio (75:25) with BMB substitution got highly accept by panel members. Even though BMB slightly increased the hardness of rusk and in muffin and increase the strength of muffin. Thus, the supplementation of BMB in baked products formulation is suitable for baking process and enrichment, since it is possibly be used as partial ingredient for substitution of wheat flour as well as being a functional ingredient in formulated bakery products because of its ability to improve the nutritional quality without ignoring the palatability.

\section{Acknowledgement}

The first author is grateful to UGC for providing financial assistance to carry out the work.

\section{References}

1. Food and Drug Regulations (2013) Consolidated Regulations. Canadian Department of Justice.

2. Gomez M, Ronda F, Caballero P, Apesteguia A (2003) Effect of dietary fiber on dough rheology and bread quality. European Food Research Technology 216: 51-56.

3. Hernandez N, Rodriguez-Alegría ME, Gonzalez F, Lopez-Munguia A (2000) Enzymatic treatment of rice bran to improve processing. JAOCS 77: 177-180.

4. Elsheikh EAE, Fadul IA, EI Tinay AH (2000 Effect of cooking on antinutritional factors and in vitro protein digestibility of faba bean grown with different nutritional regimes. Food Chem 68: 211-212
5. Kim K, Tsao R, Yang R, Cui SW (2006) Phenolic acid profiles and antioxidant activities of wheat bran extracts and the effect of hydrolysis conditions. Food Chem 95: 466-473.

6. Hotz C, Gibson RS (2007) Traditional food-processing and preparation practices to enhance the bioavailability of micronutrients in plant-based diets. J Nutr 137: 1097-1100.

7. Fernandez NM, Aranda P, Lopez-Jurado M, Urbano G, Estrella I (1993) Effect of processing on some antinutritive factors of faba beans: Influence on protein digestibility and food intake in rats. Wageningen Per: Wageningen, The Netherlands.

8. Knill CJ, Kennedy JF (2003) Degradation of cellulose under alkaline conditions. Carbohydrate Polymers 51: 281-300.

9. Daniel B (2005) Matering fiber in gastrointestinal foods. Healthy Foods European Summit.

10. AOAC (2000) Official Methods of Analysis. 17th edition. Association of Official Analytical Chemists. Washington DC, USA.

11. Hemery Y, Rouau X, Lullien-Pellerin V, Barron C, Abecassis J (2007) Dry processes to develop wheat fractions and products with enhanced nutritional quality. Journal of cereal science 46:327-347.

12. Sanz T, Salvador A, Baixauli R, Fiszman S (2009) Evaluation of four types of resistant starch in muffins. II. effects in texture, colour and consumer response. European Food Research and Technology 229: 197-204.

13. Aminah A (2000) Panduan Makmal Penilaian Sensori.

14. Baixauli R, Salvador A, Fiszman SM (2008) Textural and colour changes during storage and sensory shelf life of muffins containing resistant starch. European Food Research and Technology 226: 523-530.

15. Abdel Rahman SM, Babiker EE, Abduallahi HE (2005) Effect of fermentation on antinutritional factors and $\mathrm{HCL}$ extractability of minerals of pearl millet cultivars. J Food Sci Tech 3: 516-522.

16. Weaver CM, Kanna S (2002) Phytate and mineral bioavailability. CRC press boca raton.

17. Anitha G, Rajyalakshmi P (2005) Baby corn (Zea mays L.): Physico-chemical characteristics and use in product development. Journal of Food Science and Technology 42: 234-238.

18. Ologhobo AD, Apata DF, Oyejide A (1993) Utilization of raw jackbean (Canavalia ensiformis)and jackbean fractions in diets for broiler chicks. Br Poult Sci 34: 323-337. 